\title{
EFFECT OF OWNERSHIP CHANGE AND GROWTH ON FIRM VALUE AT THE ISSUANCE OF BONDS WITH DETACHABLE WARRANTS
}

\author{
Sekyung OH ${ }^{1}$, Woo Sung KIM² \\ ${ }^{1}$ Department of Business Administration, Konkuk University, \\ 120 Neungdong-ro Gwangjin-gu, Seoul 05029, Korea \\ ${ }^{2}$ College of Economics and Business, Hankuk University of Foreign Studies, Global Campus, \\ 81 Oedae-ro Mohyen-myeon Cheoin-gu Yongin-si, Gyeonggi-do17035, Korea \\ E-mails: ${ }^{1}$ skoh@konkuk.ac.kr; ${ }^{2}$ ab1212@konkuk.ac.kr (corresponding author)
}

Received 29 March 2015, accepted 09 July 2015

\begin{abstract}
This paper empirically explores the relationship between the issuance of bonds with detachable warrants and firm value and the relationship between growth and firm value at the issuance of such bonds. Twelve years of data for 721 issuances of 451 Korean listed firms are analyzed using a panel regression model. We find that at the issuance of bonds with detachable warrants, the change in firm value is strongly correlated with large shareholder ownership concentration and issuance form, and the effect of growth on firm value is strongly correlated with the cash flow condition of the issuing firm. The results indicate that the ownership structure and the cash flow condition of the issuing firm and the form of issuance are important determinants of the relationship between the issuance of bonds with detachable warrants and firm value; these results are applicable to an analysis of the mixed market reactions of convertible bonds or bonds with warrants issues across different countries. They also offer the policy implication that the Korean government's decision to entirely prohibit firms from issuing bonds with detachable warrants may have been excessive.
\end{abstract}

Keywords: bond with detachable warrants, firm value, ownership change, ownership level, growth, private placement.

JEL Classification: G32, G13.

\section{Introduction}

Although convertible bonds (CBs) have been more popular and issued more frequently, bonds with detachable warrants (BWs) became the preferred equity linked financing instrument in Japan and Korea until recently. However, as the evasive issuances of detachable BWs became widespread in Korea, the Korean government decided to ban their issuance entirely in 2013, resulting in the death of BW issuance markets. Previous empirical studies on the wealth effects of CBs and BWs have looked at abnormal stock returns at the announcements of $\mathrm{CB}$ and $\mathrm{BW}$ issues, but the results are mixed. The 
empirical results on the relationship between both $\mathrm{CB}$ and $\mathrm{BW}$ issuance and growth are ambiguous as well. These observations motivate us to investigate the effect of detachable BW issuance on firm value and growth.

This paper examines what effect the issuance of detachable BWs would have on firm value and whether its side effects are grave enough to justify the Korean government's prohibition, even for public offerings, let alone private placements. We investigate if the increase in ownership of large shareholders due to detachable BW issuance would adversely affect firm value. We argue that the effect of detachable BW issuance on firm value may differ depending on the ownership levels of large shareholders, as evidenced by Wruck (1989).

The second objective of this paper is to examine how growth affects firm value differently when detachable BWs are issued depending on the cash flow situation of the issuing firm. The effect of growth on firm value when detachable BWs are issued may depend on whether the money raised is used for investment expansion to pursue growth opportunities. Some firms with high growth rates and many positive NPV projects may have difficulty with external financing due to the adverse selection problem created by the information asymmetry between shareholders and bondholders. We claim that, for these firms, an increased growth rate will affect firm value positively when detachable BWs are issued. However, if the money financed through the detachable BWs are used for purposes other than investment or only cause an overinvestment problem, the opposite result may ensue.

Additionally, we examine whether there are differences in the effect of detachable BW issuance on firm value between a public offering and a private placement, since a private placement of detachable BW issuance not only causes agency problems such as asset substitution but also increases the possibility that it will be abused as a roundabout way to increase the ownership of large shareholders. Furthermore, we compare the KOSPI (Korea Composite Stock Price Index) market to KOSDAQ (Korea Securities Dealers Automated Quotation) market and compare chaebol firms to non-chaebol firms to see if the effect of detachable BW issuance on firm value differs between the two groups.

This paper contributes to an understanding of the relationship between detachable BW issuance and firm value. We find that the change in firm value at the issuance of detachable BWs is strongly correlated with the ownership concentration level of large shareholders. Hence, the wealth effects of BWs (including CBs) should be mixed, as evidenced when the ownership concentration level is not considered. We also find that the effect of growth on firm value at the issuance of detachable BWs is strongly correlated with the cash flow condition of the issuing firm. Hence, the relationship between growth and firm value at the issuance of detachable BWs should be mixed, as evidenced when the cash flow condition of the issuing firm is not considered. The results are applicable to an analysis of the mixed evidence of stock market reactions to the announcements of CBs or BWs issued from countries around the world. Another contribution of this paper is providing empirical evidence that detachable BW issuance in a public offering affects firm value positively, supporting the arguments that the Korean financial authorities should allow the issuance of detachable BWs for public offerings. 
The remainder of this paper proceeds as follows. The next section reviews the relevant literature. Section 2 develops the hypotheses. Section 3 describes the dataset and discusses the research methodology. Section 4 reports and discusses the empirical results, and the last section concludes the paper.

\section{Literature review}

Several studies argue the positive effect of BW issuance on firm value. Green (1984) suggests that BWs can reduce the agency problem between bondholders and equityholders, mitigating incentives for existing shareholders to engage in asset substitution. Jinn (2011) argues that, when firms have an underinvestment problem and cannot raise money in the public markets due to the adverse selection problem despite their growth opportunities, BW issuance in the form of private placements may positively affect firm value. Rahim et al. (2014) report that BW issuance positively affects firm value due to the tax effect for profitable firms. However, other studies claim that BW issuance affects firm value negatively. Miller and Rock (1985) argue that an external financing decision involving equity options such as BWs may reveal that management perceives the equity to be overpriced, resulting in a decline in firm value. Hennessy and Tserlukevich (2004) refute the view in Green (1984) by claiming that no warrant can eliminate asset substitution when the firm chooses volatility dynamically.

Meanwhile, the empirical literature on the wealth effects of the announcements of CBs and BWs is abundant, but the results are mixed across countries (Rahim et al. 2014). Studies in the US report significantly larger negative abnormal returns for both CBs and BWs than for those issued in other countries (Billingsley et al. 1990; Lewis et al. 2003). Kang et al. $(1995,1999)$ report insignificantly negative abnormal return for CBs and significantly positive abnormal return for BWs in Japan. Yoon (2015) reports that the short-term and long-term wealth effects of the issuances of privately-placed detachable BWs are different, depending on whether warrants are sold to the affiliated persons such as CEO or large shareholders in Korea.

Detachable BW issuance can change large shareholder ownership, which in turn affects firm value. Although there is substantial literature about the relationship between ownership and firm value, there is little research on how the ownership change due to warrant exercise after BW issuance affects firm value. Johnson et al. (2000) suggest that an increase in large shareholder ownership concentration can affect firm value negatively since it will boost managerial entrenchment, thereby fostering inefficient resource allocation within the firm and making it a more difficult acquisition target. According to the entrenchment hypothesis, owner-managers can avoid the threats of layoff and pursue their personal interests more easily by increasing their ownership concentration (Stulz 1988; Farinha 2003). Contrariwise, the convergence of interest hypothesis suggests that an increase in large shareholder ownership concentration can affect firm value positively since it will alleviate the conflict of interest between shareholders and managers (Morck et al. 1988; Davies et al. 2005).

Fama and Jensen (1983) argue that, if large shareholders are owner-managers or control professional managers effectively, the conflict of interest between minority sharehold- 
ers and managers will decrease, producing a positive effect on firm value. In particular, prior empirical studies on the relationship between ownership and firm value have reported mixed results (Villalonga, Amit 2006; Vintilă, Gherghina 2014). Furthermore, Wruck (1989) finds that the relationship between changes in ownership and changes in firm value depends on both the changes in ownership and the resulting ownership levels. Therefore, examining what effect detachable BW issuance has on firm value requires that we consider the ownership changes and the ownership levels of large shareholders at the same time.

Interestingly, theoretical models of the relationship between growth and firm value address only the issuance of CBs, and the empirical results are unclear. Barclay and Smith (1995) argue that, with more growth options in the firm's investment opportunity set, the conflict between stockholders and bondholders over the exercise of these options is greater, and stockholders have more incentives to reject positive NPV projects when the firm issues CBs. Contrariwise, Jen et al. (1997) claim that market-to-book ratio, asset growth rate, and profit growth rate show a positive correlation with stock returns and that the higher the future prospect of growth, the less negative the investor reaction to the announcement of CBs.

\section{Hypotheses}

\subsection{The relationship between the issuance of detachable BWs and firm value}

The relationship between detachable BW issuance and firm value may be positive for several reasons: BWs can mitigate agency costs and overinvestment problems, help firms with underinvestment problems and growth opportunities, and increase the value of interest tax shields. The relationship may also be negative: BWs may reveal that management perceive the equity to be overpriced, and they can also reduce ownership concentrations - revealing management pessimism or making the firm a more difficult acquisition target - and can be misused by large shareholders or managers for their own interests. Hence, the relationship between detachable BWs and firm value is an empirical matter. Our first null hypothesis is thus as follows:

H1: The issuance of detachable BWs will not affect firm value significantly.

\subsection{Effect on firm value of the ownership changes of large shareholders from warrant exercise}

It is not clear whether the ownership changes due to $\mathrm{BW}$ issuance have a positive or negative effect on firm value because they can either boost managerial entrenchment or alleviate the conflict of interest between shareholders and managers. Following Wruck (1989), we predict that the effect on firm value of an increase in large shareholder ownership concentration from a warrant exercise will differ depending on the large shareholder ownership levels. Therefore, we hypothesize that, when the large shareholder ownership level is very high, an increased large shareholder ownership will positively affect firm value, because the ownership increase from a warrant exercise will secure their management rights more firmly or help them govern professional managers more 
effectively, and will not reduce the possibility of a takeover. Contrariwise, we hypothesize that, when the large shareholder ownership level is very low, an increased large shareholder ownership will negatively affect firm value, because the ownership increase from a warrant exercise will increase the likelihood that they will pursue their own interests or fail to monitor professional managers, and will not increase the possibility of a takeover. Finally, we hypothesize that, when the large shareholder ownership level is neither very high nor very low, the effect on firm value of an ownership increase from a warrant exercise will be indecisive. We summarize our second null hypotheses as follows:

H2: The effect on firm value of a change in large shareholder ownership concentration from a warrant exercise will depend on the large shareholder ownership level.

H2-1: When the large shareholder ownership level is very high, an increase in that ownership concentration from a warrant exercise will positively affect firm value.

H2-2: When the large shareholder ownership level is very low, an increase in that ownership concentration from a warrant exercise will negatively affect firm value.

H2-3: When the large shareholder ownership level is neither very high nor very low, an increase in that ownership concentration from a warrant exercise will have an insignificant effect on firm value.

\subsection{Effect of growth on firm value at the issuance of detachable BWs}

When detachable BWs are issued, the effect of growth on firm value may depend on whether the money raised by BWs is used to increase investments and pursue growth opportunities. Consequently, we hypothesize that, when detachable BWs are issued, the effect of growth on firm value is not always positive but varies depending upon the cash flow situation of the issuing firm. Some firms with high growth rates and many positive NPV projects may have difficulty with external financing owing to the adverse selection problem created by the information asymmetry between shareholders and bondholders. In this case, when detachable BWs are issued, an increase in growth rate will affect firm value positively since the firm can solve the underinvestment problem caused by a chronically insufficient cash flow. On the other hand, we expect that, when detachable BWs are issued, an increase in growth rate will negatively affect the value of firms with good cash flows because the money financed through the detachable BWs can be used for purposes other than investment or cause an overinvestment problem. Thus, we summarize our third null hypotheses as follows:

H3: When detachable BWs are issued, the effect of growth on firm value will depend on the cash flow situation of the issuing firm.

H3-1: When detachable BWs are issued, the effect of growth on firm value will be positive if the cash flow situation of the issuing firm is poor.

H3-2: When detachable BWs are issued, the effect of growth on firm value will be negative if the cash flow situation of the issuing firm is good. 


\section{Methodology}

\subsection{Data description}

This paper examines listed Korean non-financial firms that issued detachable BWs from January 2000 to December 2011. A total of 721 issuances, including both public and private offerings, have been offered by 451 firms during the period. The data have been obtained from the Data Analysis, Retrieval, and Transfer (DART) System of the Korean Financial Supervisory Service and KISVALUE supplied by National Information and Credit Evaluation (NICE), one of Korea's three credit rating agencies.

\subsection{Model specification}

We test our hypotheses through t-tests and panel regressions. We use a panel regression model because it can control for the time-invariant unobserved firm features that we think might be correlated with the explanatory variables in our model. Furthermore, pooling samples at different points in time provides more precise estimators and test statistics with more power:

$$
\begin{aligned}
& \text { FirmValue }_{\text {it }}=\beta_{1}+\beta_{2} \text { BWdummy }_{i t}+\beta_{3} \text { AssetGr }_{i t}+\beta_{4} \text { Bigshare }_{i t}+\beta_{5} \text { BWdummy }_{\text {it }} \times \text { AssetGr }_{\text {it }}+ \\
& \beta_{6} \text { BWdummy }_{i t} \times \text { Bigshare }_{i t}+\beta_{7} \text { Profit }_{\text {it }}+\beta_{8} \text { Lnsal }_{\text {it }}+\beta_{9} \text { Age }_{i t}+\beta_{10} \text { Leverage }_{\text {it }}+\beta_{11} \text { Deficit }_{\text {it }}+ \\
& \beta_{12} \text { FreeCashFlow }_{\text {it }}+u_{i}+e_{i t} .
\end{aligned}
$$

We use Tobin's $Q$ as a proxy for firm value (McConnell, Servaes 1990; Berger, Ofek 1995). We employ this simple measure to avoid distortion due to the arbitrary assumptions about depreciation and inflation rates to estimate the firm's replacement value (Martínez-Sola et al. 2013). Moreover, Chung and Pruitt (1994) demonstrate that at least $96.6 \%$ of the variability of Tobin's $Q$ is explained by the proxy market value of equity plus book value of total debt to book value of total assets.

We use three key variables, $B W$ dummy, Asset $G r$, and Bigshare, to test our hypotheses. To see how detachable BW issuance affects firm value, we consider $B W$ dummy variable ( 1 for detachable BW-issuing firms and 0 otherwise). We consider AssetGr as a proxy variable for the asset growth rate. We include asset growth rate as an explanatory variable because high-growth firms that are vulnerable to agency costs and asymmetric information prefer to issue equity-linked securities (Lewis et al. 2003). We use Bigshare as a proxy variable for large shareholder ownership to measure the effect of changes in large shareholder ownership from a warrant exercise. Bigshare is measured by summing up the ownership percentage of the first large shareholder and that of its relatives and affiliated companies. Since the relationship between changes in ownership and changes in firm value depend on both the changes in ownership and the resulting ownership levels, as evidenced in Wruck (1989), we divide the sample into four equal groups based on the large shareholder ownership level (group 1 if ownership $<15 \%$; group 2 if $15 \% \leq$ ownership $<21 \%$; group 3 if $21 \% \leq$ ownership $<29 \%$; and group 4 if $29 \% \leq$ ownership). Furthermore, to measure the interaction effects of detachable BW issuance 
with growth and large shareholder ownership, we multiply the $A s s e t G r$ variable and the Bigshare variable by the $B W$ dummy variable, respectively.

For control variables, we use Profit as a proxy variable for profitability, measured by EBIT (Earnings Before Interests and Taxes) divided by total assets, or the profitability of assets-in-place (Lewis et al. 2003). As low profitability increases the debt-related costs of external finance, low-profitable firms will prefer BWs as an external financing source. We use LnSale as a proxy variable for firm size, the natural logarithm of total sales (Krishnaswami, Yaman 2008; Eisdorfer 2011). We use Age as a proxy variable for firm age, defined as the natural logarithm of the difference between year 2011 and the year of the firm's founding. We use Leverage as a proxy variable to analyze the impact of BW issuance on financial distress costs, measured as total debt divided by total assets. We use Deficit as a proxy variable for deficit of money, measured by subtracting the summation of cash dividend payouts, net capital expenditure, change in net working capital, and the current portion of long-term debts from after-tax EBIT and then dividing by total assets. A significant lack of money increases the costs of debt financing; thus, the more serious the lack of money, the higher the chance that a firm will issue BWs. We use FreeCashFlow as a proxy variable for a firm's cash flow situation, measured as total free cash flow divided by total assets.

\section{Empirical results}

\subsection{Descriptive statistics}

Table 1 presents the descriptive statistics for the variables used in our analysis. The first column of Table 1 presents the statistics for the whole sample, showing that most variables have large standard deviations and skewed distributions. On average, Tobin's $Q$ is about 1.039, implying that the market value of Korean listed non-financial companies is almost equal to (or slightly less than) their book value. The average of AssetGr is 0.267 , showing a large difference in asset growth rates between firms, and the distribution of asset growth rates is highly skewed to the right. Large shareholder ownership, Bigshare, is $24.46 \%$ on average.

We use a parametric t-test to examine whether firm characteristics will differ between detachable BW-issuing firms and non-issuing firms (see Table 1). The averages of Tobin's $Q$ and Asset $G r$ for detachable BW-issuing firms are significantly higher than those for non-issuing firms. The average of Bigshare for detachable BW-issuing firms is significantly lower than that for non-issuing firms, implying that there may be more incentives for the large shareholders of detachable BW-issuing firms to increase their shares from a warrant exercise. On average, detachable BW-issuing firms have a significantly lower Profit, LnSale, Age, and FreeCashFlow but a significantly higher Leverage and Deficit than do non-issuing firms. Table 2, the correlation matrix, shows that there are no high correlations between independent variables, indicating the absence of a multicollinearity problem. 
Table 1. Descriptive statistics

\begin{tabular}{|c|c|c|c|c|c|c|c|c|c|c|c|c|}
\hline \multirow[t]{2}{*}{ Variables } & \multicolumn{4}{|c|}{ All firms } & \multicolumn{3}{|c|}{$\begin{array}{c}\text { Detachable } \\
\text { BW-issuing firms }\end{array}$} & \multicolumn{3}{|c|}{ Non-issuing firms } & \multirow{2}{*}{$\begin{array}{c}\text { Mean } \\
\text { Differ- } \\
\text { ence }\end{array}$} & \multirow[t]{2}{*}{ p-value } \\
\hline & Obs. & Mean & Median & S.D. & Obs & Mean & Median & Obs. & Mean & Median & & \\
\hline Tobin's Q & 17773 & 1.04 & 0.85 & 0.99 & 5914 & 1.21 & 0.96 & 11859 & 0.95 & 0.81 & $0.25 * * *$ & $<.0001$ \\
\hline AssetGr & 17616 & 0.27 & 0.09 & 1.53 & 5848 & 0.36 & 0.11 & 11768 & 0.22 & 0.09 & $0.13 * * *$ & $<.0001$ \\
\hline Bigshare & 17885 & 24.46 & 22.37 & 17.09 & 5991 & 20.98 & 19.17 & 11894 & 26.22 & 23.94 & $-5.24 * * *$ & $<.0001$ \\
\hline Profit & 17774 & 0.05 & 0.05 & 0.16 & 5915 & 0.02 & 0.03 & 11859 & 0.07 & 0.06 & $-0.05 * * *$ & $<.0001$ \\
\hline LnSale & 17725 & 24.95 & 24.85 & 1.78 & 5889 & 24.32 & 24.29 & 11836 & 25.26 & 25.17 & $-0.94 * * *$ & $<.0001$ \\
\hline Age & 17913 & 23.12 & 21.00 & 15.58 & 6026 & 18.25 & 15.00 & 11887 & 25.58 & 24.00 & $-7.33 * * *$ & $<.0001$ \\
\hline Deficit & 17962 & 0.16 & 0.02 & 1.09 & 6060 & 0.16 & 0.02 & 11902 & 0.15 & 0.02 & 0.01 & 0.5744 \\
\hline Leverage & 17964 & 0.44 & 0.44 & 0.37 & 6060 & 0.48 & 0.47 & 11904 & 0.43 & 0.42 & $0.05 * * *$ & $<.0001$ \\
\hline FreeCashFlow & 16643 & 0.00 & 0.00 & 0.33 & 5095 & -0.01 & 0.00 & 11548 & 0.01 & 0.00 & $-0.02 * *$ & 0.021 \\
\hline
\end{tabular}

Note: $* * * * *$, and $*$ represent $1 \%, 5 \%$, and $10 \%$ significance levels, respectively.

Source: authors' calculations and estimation.

Table 2. Correlation matrix

\begin{tabular}{|c|c|c|c|c|c|c|c|c|c|}
\hline & Tobin's Q & AssetGr & Profit & LnSale & Age & Leverage & Deficit & FreeCashFlow & Bigshare \\
\hline Tobin's Q & 1 & & & & & & & & \\
\hline AssetGr & 0.01 & 1 & & & & & & & \\
\hline Profit & $-0.13 * * *$ & $0.06^{* * *}$ & 1 & & & & & & \\
\hline LnSale & $-0.02 * * *$ & $-0.12 * * *$ & $0.14 * * *$ & 1 & & & & & \\
\hline Age & $-0.05 * * *$ & $-0.13 * * *$ & $-0.04 * * *$ & $0.49^{* * *}$ & 1 & & & & \\
\hline Leverage & $0.26^{* * *}$ & $-0.02 * * *$ & $-0.25 * * *$ & $0.07 * * *$ & $0.04 * * *$ & 1 & & & \\
\hline Deficit & 0.004 & $0.01 *$ & $0.02 * *$ & $-0.02 * * *$ & $-0.03 * * *$ & -0.01 & 1 & & \\
\hline FreeCashFlow & 0.01 & $-0.02 * * *$ & $0.04 * * *$ & $0.07 * * *$ & $0.03 * * *$ & -0.01 & 0.003 & 1 & \\
\hline Bigshare & $0.01^{*}$ & $-0.06 * * *$ & $0.06^{* * *}$ & $0.18 * * *$ & $0.08 * * *$ & $-0.02 * *$ & $-0.03 * * *$ & $-0.03 * * *$ & 1 \\
\hline
\end{tabular}

Note: $* * * * *$, and $*$ represent $1 \%, 5 \%$, and $10 \%$ significance levels, respectively.

Source: authors' estimation.

\subsection{How does a detachable $B W$ issuance influence firm value?}

This section examines how detachable BW issuance affects firm value through a panel regression model. The coefficient of $B W$ dummy in column (1) of Table 3 shows that detachable BW issuance has a negative and insignificant effect on firm value, supporting Hypothesis 1. Table 3 shows that the coefficient of Asset $G r$ is significantly positive but that the coefficient of the interaction term $B W$ dummy $\times A s s e t G r$ is significantly negative. This result may suggest that growth has a generally positive impact on firm value but that the effect of growth on firm value is smaller for detachable BW-issuing firms than for non-issuing firms. Table 3 also shows that the coefficient of Bigshare 
is significantly negative but that the coefficient of the interaction term $B W$ dummy $\times$ Bigshare is negative and insignificant. This result may suggest that an increase in large shareholder ownership has a generally negative effect on firm value but that the effect of a change in large shareholder ownership on firm value may be different for detachable BW-issuing firms than for non-issuing firms.

Table 3. Relation between issuance of detachable BWs and firm value

\begin{tabular}{|c|c|c|c|}
\hline \multirow{2}{*}{ Variables } & \multicolumn{3}{|c|}{ Tobin's Q } \\
\hline & (1) & (2) & (3) \\
\hline Constant & $\begin{array}{c}4.177 * * * \\
(12.522)\end{array}$ & $\begin{array}{c}4.166^{* * *} \\
(12.509)\end{array}$ & $\begin{array}{c}4.175 * * * \\
(12.511)\end{array}$ \\
\hline$B W$ dummy & $\begin{array}{c}-0.017 \\
(-0.526)\end{array}$ & & \\
\hline$B W$ dummy $\times$ Asset $G r$ & & $\begin{array}{c}-0.156^{* * *} \\
(-6.234)\end{array}$ & \\
\hline$B W$ dummy $\times$ Bigshare & & & $\begin{array}{c}-0.001 \\
(-0.412)\end{array}$ \\
\hline AssetGr & $\begin{array}{c}0.051 * * * \\
(8.272)\end{array}$ & $\begin{array}{c}0.060 * * * \\
(9.491)\end{array}$ & $\begin{array}{c}0.051 * * * \\
(8.270)\end{array}$ \\
\hline Bigshare & $\begin{array}{c}-0.003 * * * \\
(-4.014)\end{array}$ & $\begin{array}{c}-0.003 * * * \\
(-3.998)\end{array}$ & $\begin{array}{c}-0.003 * * * \\
(-3.970)\end{array}$ \\
\hline Profit & $\begin{array}{c}0.588 * * * \\
(7.293)\end{array}$ & $\begin{array}{c}0.592 * * * \\
(7.357)\end{array}$ & $\begin{array}{c}0.588^{* * * *} \\
(7.292)\end{array}$ \\
\hline LnSale & $\begin{array}{c}-0.158^{* * *} \\
(-11.435)\end{array}$ & $\begin{array}{c}-0.158^{* * *} \\
(-11.428)\end{array}$ & $\begin{array}{c}-0.158^{* * * *} \\
(-11.428)\end{array}$ \\
\hline Age & $\begin{array}{c}0.026^{* * *} \\
(11.418)\end{array}$ & $\begin{array}{c}0.026^{* * *} \\
(11.528)\end{array}$ & $\begin{array}{c}0.026^{* * *} \\
(11.422)\end{array}$ \\
\hline Leverage & $\begin{array}{c}0.810 * * * \\
(39.102)\end{array}$ & $\begin{array}{l}0.811 * * * \\
(39.201)\end{array}$ & $\begin{array}{c}0.810^{* * *} \\
(39.098)\end{array}$ \\
\hline Deficit & $\begin{array}{c}0.013 \\
(1.590)\end{array}$ & $\begin{array}{c}0.013 \\
(1.586)\end{array}$ & $\begin{array}{c}0.013 \\
(1.591)\end{array}$ \\
\hline FreeCashFlow & $\begin{array}{c}0.759 * * * \\
(39.844)\end{array}$ & $\begin{array}{c}0.750 * * * \\
(39.317)\end{array}$ & $\begin{array}{c}0.759 * * * \\
(39.851)\end{array}$ \\
\hline Fixed effects & Yes & Yes & Yes \\
\hline Firms group & 1397 & 1397 & 1397 \\
\hline Total observations & 13,570 & 13,570 & 13,570 \\
\hline Adjusted R-squared & 0.475 & 0.477 & 0.475 \\
\hline$F$-statistic & $9.755 * * *$ & $9.814 * * *$ & $9.755 * * *$ \\
\hline
\end{tabular}

Note: $* * * * *$, and $*$ represent $1 \%, 5 \%$, and $10 \%$ significance levels, respectively. Source: authors' estimates. 


\subsection{How does a change in the large shareholder ownership from a warrant exercise affect firm value?}

Table 4 shows the results concerning the relationship between the change in large shareholder ownership and firm value depending on which group the large shareholder ownership level falls in. Column (4) shows the results when the level exceeds $30 \%$. In this case, the interaction term $B W$ dummy $\times$ Bigshare has a positive and significant coefficient $(+0.179)$ at the $1 \%$ significant level, indicating that an increase in large shareholder

Table 4. Effect on firm value of changes of large shareholder ownership from a warrant exercise

\begin{tabular}{|c|c|c|c|c|}
\hline \multirow{2}{*}{ Variables } & \multicolumn{4}{|c|}{ Tobin's Q } \\
\hline & (1) & (2) & (3) & (4) \\
\hline Constant & $\begin{array}{c}3.994 * * * \\
(12.082)\end{array}$ & $\begin{array}{c}3.996 * * * \\
(12.088)\end{array}$ & $\begin{array}{l}3.992 * * * \\
(12.072)\end{array}$ & $\begin{array}{l}4.002 * * * \\
(12.106)\end{array}$ \\
\hline BW dummy * Bigshare [0-14\%] & $\begin{array}{l}-0.097^{*} \\
-(1.653)\end{array}$ & & & \\
\hline BW dummy * Bigshare [15-20\%] & & $\begin{array}{c}0.004 \\
(0.073)\end{array}$ & & \\
\hline BW dummy * Bigshare [21-29\%] & & & $\begin{array}{c}-0.039 \\
-(0.611)\end{array}$ & \\
\hline BW dummy * Bigshare $[30 \%+]$ & & & & $\begin{array}{c}0.179 * * * \\
(2.249)\end{array}$ \\
\hline AssetGr & $\begin{array}{c}0.051 * * * \\
(8.221)\end{array}$ & $\begin{array}{c}0.051 * * * \\
(8.209)\end{array}$ & $\begin{array}{c}0.051 * * * \\
(8.223)\end{array}$ & $\begin{array}{c}0.051 * * * \\
(8.199)\end{array}$ \\
\hline Profit & $\begin{array}{c}0.565 * * * \\
(7.024)\end{array}$ & $\begin{array}{c}0.567 * * * \\
(7.045)\end{array}$ & $\begin{array}{c}0.567 * * * \\
(7.047)\end{array}$ & $\begin{array}{c}0.567 * * * \\
(7.054)\end{array}$ \\
\hline Lnsale & $\begin{array}{c}-0.154 * * * \\
-(11.142)\end{array}$ & $\begin{array}{c}-0.154 * * * \\
-(11.141)\end{array}$ & $\begin{array}{c}-0.154 * * * \\
-(11.133)\end{array}$ & $\begin{array}{c}-0.154 * * * \\
-(11.145)\end{array}$ \\
\hline Age & $\begin{array}{c}0.025 * * * \\
(11.167)\end{array}$ & $\begin{array}{c}0.025^{* * * *} \\
(11.081)\end{array}$ & $\begin{array}{c}0.025 * * * \\
(11.122)\end{array}$ & $\begin{array}{c}0.025 * * * \\
(11.000)\end{array}$ \\
\hline Leverage & $\begin{array}{c}0.814 * * * \\
(39.334)\end{array}$ & $\begin{array}{c}0.815 * * * \\
(39.365)\end{array}$ & $\begin{array}{c}0.815 * * * \\
(39.380)\end{array}$ & $\begin{array}{c}0.814 * * * \\
(39.331)\end{array}$ \\
\hline Deficit & $\begin{array}{c}0.014 \\
(1.616)\end{array}$ & $\begin{array}{c}0.014 \\
(1.632)\end{array}$ & $\begin{array}{c}0.014 \\
(1.631)\end{array}$ & $\begin{array}{c}0.014 \\
(1.627)\end{array}$ \\
\hline FreeCashFlow & $\begin{array}{l}0.760 * * * \\
(39.882)\end{array}$ & $\begin{array}{c}0.760 * * * \\
(39.878)\end{array}$ & $\begin{array}{c}0.760 * * * \\
(39.855)\end{array}$ & $\begin{array}{l}0.760 * * * \\
(39.907)\end{array}$ \\
\hline Fixed effects & Yes & Yes & Yes & Yes \\
\hline Firm groups & 1397 & 1397 & 1397 & 1397 \\
\hline Total observations & 13571 & 13571 & 13571 & 13571 \\
\hline Adjusted R-squared & 0.475 & 0.475 & 0.475 & 0.475 \\
\hline$F$-statistic & $9.743 * * *$ & $9.739 * * *$ & $9.739 * * *$ & $9.746^{* * *}$ \\
\hline
\end{tabular}

Note: $* * *, * *$, and $*$ represent $1 \%, 5 \%$ and $10 \%$ significance levels, respectively. Source: authors' estimates. 
ownership concentration from a warrant exercise will have a strongly positive effect on firm value when the large shareholder ownership level is very high, which is consistent with Hypothesis 2-1. Column (1) shows the results when the large shareholder ownership level is below $15 \%$. In this case, the interaction term $B W$ dummy $\times$ Bigshare has a negative and significant coefficient $(-0.097)$ at the $10 \%$ significant level, indicating that an increase in large shareholder ownership concentration from a warrant exercise will have a negative effect on firm value when the large shareholder ownership level is very low, which is consistent with Hypothesis 2-2. Columns (2) and (3) show the results when the large shareholder ownership levels fall between $15 \%$ and $21 \%$ and between $21 \%$ and $30 \%$, respectively. These results are statistically insignificant, as predicted by Hypothesis 2-3.

\subsection{How does a change in growth rate affect firm value when detachable BWs are issued?}

We divide the sample into two groups - one with more free cash flow than the average of all the firms in the sample and the other with less. Table 5 shows the results concerning the relationship between growth rate and firm value depending on the cash flow situation of detachable BW-issuing firms. Column (1) shows the results for the high free cash flow group. In this case, the interaction term $B W$ dummy $\times$ AssetGr has a negative and significant coefficient $(-0.194)$ at the $1 \%$ significance level, indicating that an increase in growth rate will have a strongly negative impact on firm value when the cash flow situation of the issuing firm is good, which is consistent with Hypothesis 3-2. For the low free cash flow group, column (2) shows that the interaction term $B W$ dummy $\times$ Asset $G r$ has a statistically insignificant and negative coefficient, rejecting Hypothesis 3-1.

\subsection{Comparisons between private and public offerings, KOSPI and KOSDAQ firms, and chaebol and non-chaebol firms}

In this section, we examine only the firms that issue detachable BWs. Column (1) of Table 6 shows that the public dummy ( 1 for public offerings and 0 for private placements) has a significant and positive coefficient $(+0.107)$ at the $5 \%$ significance level, suggesting that the issuance of detachable BWs has a positive effect on firm value when it is issued in the form of a public offering rather than a private placement. This result is in line with the markets' general concern about private sales of detachable BWs and also implies that public offerings of detachable BWs may not be as problematic as private placements in Korea.

Furthermore, Column (2) of Table 6 shows that the KOSPI dummy (1 for KOSPI firms and 0 for KOSDAQ firms) has a significant and negative coefficient $(-0.286)$ at the $1 \%$ significance level, suggesting that detachable BW issuance has a negative effect on firm value when it is issued by KOSPI firms, a result perhaps influenced by the markets' concerns about why KOSPI firms would issue detachable BWs even if they could use more general financing vehicles. Finally, Column (3) of Table 6 shows that the chaebol dummy ( 1 for chaebol firms and 0 for non-chaebol firms) has a positive but insignificant coefficient, suggesting that the effect on firm value of detachable BW issuance may not differ between chaebol and non-chaebol firms. 
S. Oh, W. S. Kim. Effect of ownership change and growth on firm value at the issuance of bonds ...

Table 5. Effect of growth on firm value for detachable BW-issuing firms

\begin{tabular}{|c|c|c|}
\hline \multirow{2}{*}{ Variables } & \multicolumn{2}{|c|}{ Tobin's Q } \\
\hline & High free cash flow group & Low free cash flow group \\
\hline Constant & $\begin{array}{c}0.708 \\
(1.763)\end{array}$ & $\begin{array}{c}-1.741 \\
-(5.912)\end{array}$ \\
\hline$B W$ dummy *Asset $G r$ & $\begin{array}{c}-0.194 * * * \\
-(6.229)\end{array}$ & $\begin{array}{c}-0.012 \\
-(0.319)\end{array}$ \\
\hline Bigshare & $\begin{array}{c}0.003 * * * \\
(3.448)\end{array}$ & $\begin{array}{c}0.002 * * \\
(2.408)\end{array}$ \\
\hline Profit & $\begin{array}{c}0.266^{* *} \\
(2.345)\end{array}$ & $\begin{array}{c}-0.467 * * * \\
-(6.089)\end{array}$ \\
\hline Lnsale & $\begin{array}{c}-0.054 * * * \\
-(3.180)\end{array}$ & $\begin{array}{c}0.065^{* * *} * \\
(4.913)\end{array}$ \\
\hline Age & $\begin{array}{c}0.048 * * * \\
(14.476)\end{array}$ & $\begin{array}{c}0.038 * * * \\
(13.520)\end{array}$ \\
\hline Leverage & $\begin{array}{c}0.692 * * * \\
(10.222)\end{array}$ & $\begin{array}{c}0.848 * * * \\
(41.141)\end{array}$ \\
\hline Deficit & $\begin{array}{c}0.003 \\
(0.386) \\
\end{array}$ & $\begin{array}{c}-0.004 \\
-(0.453) \\
\end{array}$ \\
\hline Fixed effect & Yes & Yes \\
\hline Firms group & 667 & 830 \\
\hline Total observations & 7915 & 9604 \\
\hline Adjusted R-squared & 0.229 & 0.408 \\
\hline$F$-statistic & $4.504 * * *$ & $8.917 * * *$ \\
\hline
\end{tabular}

Note: $* * *, * *$ and $*$ represent $1 \%, 5 \%$ and $10 \%$ significance levels, respectively. Source: authors' estimates.

Table 6. Comparisons between public and private offerings, KOSPI and KOSDAQ firms and chaebol and non-chaebol firms

\begin{tabular}{lccc}
\hline \multirow{2}{*}{ Variables } & \multicolumn{3}{c}{ Tobin's Q } \\
\cline { 2 - 4 } & $\begin{array}{c}1.590^{* * *} \\
(4.436)\end{array}$ & $\begin{array}{c}2.570^{* * *} \\
(7.523)\end{array}$ & $\begin{array}{c}3.142^{* * *} \\
(8.898)\end{array}$ \\
\hline Constant & $\begin{array}{c}0.107^{* *} \\
\text { Public Dummy }\end{array}$ & $(2.182)$ & \\
\hline \multirow{2}{*}{ KOSPI Dummy } & & $-0.286^{* * *}$ & \\
& & $-(5.354)$ & 0.075 \\
Chaebol Dummy & & & $(0.952)$ \\
\hline \multirow{2}{*}{ Bigshare } & 0.001 & 0.001 & 0.002 \\
& $(0.564)$ & $(1.255)$ & $(1.367)$ \\
\hline
\end{tabular}


End of Table 6

\begin{tabular}{|c|c|c|c|}
\hline \multirow{2}{*}{ Variables } & \multicolumn{3}{|c|}{ Tobin's Q } \\
\hline & (1) Public vs. Private & (2) KOSPI vs. KOSDAQ & (3) Chaebol vs. non-chaebol \\
\hline AssetGr & $\begin{array}{c}0.033 * * * \\
(3.723)\end{array}$ & $\begin{array}{c}0.031 * * * \\
(3.540)\end{array}$ & $\begin{array}{c}0.029 * * * \\
(3.310)\end{array}$ \\
\hline Profit & $\begin{array}{c}-1.586^{* * *} \\
(-9.681)\end{array}$ & $\begin{array}{c}-0.905^{* * *} \\
-(6.604)\end{array}$ & $\begin{array}{c}-0.860^{* * *} \\
-(6.245)\end{array}$ \\
\hline Lnsale & $\begin{array}{c}-0.011 \\
(-0.713)\end{array}$ & $\begin{array}{c}-0.073 * * * \\
-(5.026)\end{array}$ & $\begin{array}{c}-0.096^{* * *} \\
-(6.334)\end{array}$ \\
\hline Age & $\begin{array}{c}0.001 \\
(0.308)\end{array}$ & $\begin{array}{c}0.005 * * * \\
(3.075)\end{array}$ & $\begin{array}{c}0.001 \\
(0.473)\end{array}$ \\
\hline Leverage & $\begin{array}{c}-0.311^{* * *} \\
(-3.463)\end{array}$ & $\begin{array}{c}0.783^{* * *} \\
(24.727)\end{array}$ & $\begin{array}{c}0.770 * * * \\
(24.289)\end{array}$ \\
\hline Deficit & $\begin{array}{c}0.013 \\
(0.592)\end{array}$ & $\begin{array}{c}0.006 \\
(0.310)\end{array}$ & $\begin{array}{c}0.004 \\
(0.211)\end{array}$ \\
\hline FreeCashFlow & $\begin{array}{l}0.926 * * * \\
(22.825)\end{array}$ & $\begin{array}{c}0.888 * * * \\
(27.921)\end{array}$ & $\begin{array}{c}0.883 * * * \\
(27.641)\end{array}$ \\
\hline Fixed effects & No & No & No \\
\hline Firm groups & 336 & 435 & 435 \\
\hline Total observations & 3852 & 5018 & 5018 \\
\hline $\begin{array}{l}\text { Adjusted } \\
R \text {-squared }\end{array}$ & 0.142 & 0.245 & 0.241 \\
\hline$F$-statistic & $71.627 * * *$ & $182.002 * * *$ & $177.932 * * *$ \\
\hline
\end{tabular}

Note: $* * *, * *$, and $*$ represent $1 \%, 5 \%$ and $10 \%$ significance levels, respectively.

Source: authors' estimates.

\section{Conclusions}

We find that a change in large shareholder ownership concentration from a warrant exercise affects firm value differently depending on the level of large shareholder ownership and that detachable BW issuance has a positive effect on firm value when it is issued in the form of a public offering. These findings should lead to a new discussion about whether the Korean government's complete ban on detachable BWs was appropriate. We also find that the effect of growth on firm value at the issuance of detachable BWs is strongly correlated with the cash flow condition of an issuing firm.

These results indicate that the ownership structure and cash flow condition of the issuing firm and the form of issuance are important determinants of the relationship between the issuance of detachable BWs and firm value. To our knowledge, we are the first to empirically test these issues. Although the findings are derived from data on and an analysis of Korean firms, they are pertinent to other countries as well. Furthermore, they are applicable to the analyses of the mixed market reactions to $\mathrm{CB}$ and $\mathrm{BW}$ issuances across different countries and for different periods. 
This paper has two limitations. First, we do not consider the period from 2012 to 2013, during which many firms issued detachable BWs until the amendment to the Capital Markets and Financial Investment Business Act to prohibit listed companies from issuing detachable BWs came into effect at the end of August 2013. Second, we could not examine how much the ownership concentration actually changed due to the exercise of warrants by large shareholder.

\section{Acknowledgements}

This paper was supported by Konkuk University in 2013.

\section{References}

Barclay, M.; Smith, C. 1995. The maturity structure of corporate debt, Journal of Finance 49: 609-631. http://dx.doi.org/10.1111/j.1540-6261.1995.tb04797.x

Berger, P. G.; Ofek, E. 1995. Diversification's effect on firm value, Journal of Financial Economics 37(1): 39-65. http://dx.doi.org/10.1016/0304-405x(94)00798-6

Billingsley, R. S.; Lamy, R. E.; Smith, D. M. 1990. Units of debt with warrants: evidence of the penalty-free issuance of an equity like security, Journal of Financial Research 13(3): 187-199.

http://dx.doi.org/10.1111/j.1475-6803.1990.tb00549.x

Chung, K. H.; Pruitt, S. W. 1994. A simple approximation of Tobin's q, Financial Management 23(3): 70-74. http://dx.doi.org/10.2307/3665623

Davies, J. R.; Hillier, D.; McColgan, P. 2005. Ownership structure, managerial behavior and corporate value, Journal of Corporate Finance 11(4): 645-660.

http://dx.doi.org/10.1016/j.jcorpfin.2004.07.001

Eisdorfer, A. 2011. Why is convertible debt subordinated? An investment-based agency theory, Financial Review 46(1): 43-65. http://dx.doi.org/10.1111/j.1540-6288.2010.00289.x

Fama, E. F.; Jensen, M. C. 1983. Separation of ownership and control, Journal of Law and Economics 26(2): 301-325. http://dx.doi.org/10.1086/467037

Farinha, J. 2003. Dividend policy, corporate governance and the managerial entrenchment hypothesis: an empirical analysis, Journal of Business Finance \& Accounting 30: 1173-1209.

http://dx.doi.org/10.2139/ssrn.313976

Green, R. C. 1984. Investment incentives, debt, and warrant, Journal of Financial Economics 13: $116-136$.

http://dx.doi.org/10.1016/0304-405x(84)90034-5

Hennessy, C.; Tserlukevich, Y. 2004. Dynamic hedging incentives, debt, and warrants, in EFA 2004 Maastricht Meetings Paper No. 5094. http://dx.doi.org/10.2139/ssrn.559409

Jen, F.; Choi, D.; Lee, S. 1997. Some new evidence on why companies use convertible bonds, Journal of Applied Corporate Finance 10: 44-53.

http://dx.doi.org/10.1111/j.1745-6622.1997.tb00124.x

Jinn, T. H. 2011. A study on the valuation effect of private placements of bond with warrant, The Korean Journal of Financial Engineering, 10(3): 73-90.

Johnson, S.; Boone, P.; Breach, A.; Friedman, E. 2000. Corporate governance in the Asian financial crisis 1997-1998, Journal of Financial Economics 58: 141-186.

http://dx.doi.org/10.1016/s0304-405x(00)00069-6

Kang, J. K.; Kim, Y. C.; Park, K. J.; Stulz, R. M. 1995. An analysis of the wealth effects of Japanese offshore dollar-denominated convertible and warrant bond issues, Journal of Financial and Quantitative Analysis 30(2): 257-270. http://dx.doi.org/10.2307/2331120 
Kang, J. K.; Kim, Y. C.; Stulz, R. M. 1999. The underreaction hypothesis and the new issue puzzle: evidence from Japan, Review of Financial Studies 12(3): 519-534.

http://dx.doi.org/10.1093/rfs/12.3.519

Krishnaswami, S.: Yaman, D. 2008. The role of convertible bonds in alleviating contracting costs, The Quarterly Review of Economics and Finance 48(4): 792-816.

http://dx.doi.org/10.2139/ssrn.492864

Lewis, C. M.; Rogalski, R. J.; Seward, J. K. 2003. Industry conditions, growth opportunities and market reactions to convertible debt financing decisions, Journal of Banking and Finance 27: 153-181. http://dx.doi.org/10.1016/s0378-4266(01)00212-6

Martínez-Sola, C.; García-Teruel, P. J.; Martínez-Solano, P. 2013. Trade credit policy and firm value, Accounting \& Finance 53(3): 791-808. http://dx.doi.org/10.1111/j.1467-629x.2012.00488.x

McConnell, J. J.; Servaes, H. 1990. Additional evidence on equity ownership and corporate value, Journal of Financial Economics 27(2): 595-612. http://dx.doi.org/10.1016/0304-405x(90)90069-c

Miller, M. H.; Rock, K. 1985. Dividend policy under asymmetric information, The Journal of Finance 40(4): 1031-1051. http://dx.doi.org/10.1111/j.1540-6261.1985.tb02362.x

Morck, R.; Shleifer, A.; Vishny, R. M. 1988. Management ownership and market valuation, Journal of Financial Economics 20: 293-315. http://dx.doi.org/10.1016/0304-405x(88)90048-7

Rahim, N. A.; Goodacre, A.; Veld, C. 2014. Wealth effects of convertible-bond and warrant-bond offerings: a meta analysis, The European Journal of Finance 20(4): 380-398.

http://dx.doi.org/10.1080/1351847x.2012.712920

Stulz, R. M. 1988. Managerial control of voting rights: financing policies and the market for corporate control, Journal of Financial Economics 20: 25-54.

http://dx.doi.org/10.1016/0304-405x(88)90039-6

Villalonga, B.; Amit, R. 2006. How do family ownership, control and management affect firm value?, Journal of Financial Economics 80(2): 385-417.

http://dx.doi.org/10.1016/j.jfineco.2004.12.005

Vintilă, G.; Gherghina, Ş. C. 2014. The impact of ownership concentration on firm value. Empirical study of the Bucharest stock exchange listed companies, Procedia Economics and Finance 15: 271-279. http://dx.doi.org/10.1016/s2212-5671(14)00500-0

Wruck, K. H. 1989. Equity ownership concentration and firm value: evidence from private equity financings, Journal of Financial Economics 23: 3-28.

http://dx.doi.org/10.1016/0304-405x(89)90003-2

Yoon, P. S. 2015. The short-term and long-term wealth effects of privately-placed detachable bond with warrant issuances, Korean Journal of Financial Studies 44(3): 517-546.

Sekyung OH is a Professor of Finance at Konkuk University. His research interests include corporate finance, risk management and capital markets. He has published in Emerging Markets Finance and Trade, Asia-Pacific Journal of Financial Studies, International Review of Economics and Finance, Asia Review of Financial Research, and wrote several books with his colleagues. He had earned his doctoral degree at the Wharton School of University of Pennsylvania and served as a visiting researcher at the Hebrew University and taught at the California State University at San Marcos. He received the Best Paper Award in the pension fund area at the 2014 annual meeting of the joint academic conference of five Korean-American Finance Associations.

Woo Sung KIM is a Lecturer in Finance at Konkuk University and Hankuk University of Foreign Studies. His current research interests include corporate finance and business ethics. He has published in Asia Review of Financial Research, Korean Academy of International Business. He received his $\mathrm{PhD}$ in Finance in 2011. 